\section{Berit Berg}

Professor i sosialt arbeid

og forskningssjef ved NTNU Samfunnsforskning

\title{
Barn på flukt
}

Barn på flukt er særlig sårbare.

Forutsigbarheten og de trygge

rammene som barn trenger, er det vanskelig å gi dem i en flyktning-

tilværelse.

Høsten 2014 besøkte jeg en av verden største flyktningleire - Zaatari i Jordan, nær grensen til Syria. Der bodde det 80000 mennesker i telt og provisoriske bygninger. Mange hadde bodd der siden leiren åpnet i 2012. De kom dit med håpet om en snarlig løsning for Syria, men etter hvert begynte mange å miste motet. Uker ble til måneder, måneder ble til år.

For et barn er tre år lenge. Enda lenger blir det hvis man tar med tiden med krig og usikkerhet i hjemlandet, månedene det tok å flykte og perioden de måtte vente på svar på asylsøknaden. Mange husker ikke annet enn krigen, flukten og ventetiden.

Hver tredje asylsøker som kom til Norge i 2015 var et barn. Av disse var mer enn halvparten enslige mindreårige - barn og unge som kom hit til landet uten foreldre eller andre omsorgspersoner. De ble en del av statistikken som norske politikere de siste månedene har omtalt som den europeiske «flyktningkrisen». 31000 asylsøkere, 10000 barn, 5300 enslige mindreårige. Én million mennesker søkte asyl i Europa i 2015 - én million av verdens 60 millioner flyktninger. Om lag 40 millioner er flyktninger i eget land, såkalt internt fordrevne. Av de resterende 20 millionene befinner de fleste seg i nærområdene i land som er preget av politisk ustabilitet og store levekårsutfordringer.

Libanon, Tyrkia og Jordan er land som hver for seg har tatt imot rundt én million syriske flyktninger. Dette kommer på toppen av millioner som har flyktet fra andre land i regionen. Nærområdene står midt oppi en humanitær krise. Mens man i Europa er opptatt avå hindre flere i å komme, opplever man i nærområdene at den humanitære bistanden fra verdenssamfunnet er altfor liten til å kunne sikre asylsøkere tak over hodet, mat, medisinsk hjelp og - ikke minst - trygghet.

Årsakene til at mennesker blir drevet på flukt er politiske, men selve flyktningspørsmålet har også en humanitær dimensjon. På individuelt nivå handler det om å gi mennesker på flukt beskyttelse mot krig og forfølgelse. Våre forpliktelser overfor barn på flukt er nedfelt både i Barnekonvensjonen, i Flyktningkonvensjonen og i Den europeiske menneskerettighetskonvensjon.

Barn på flukt er i en særlig sårbar situasjon. Spenningen mellom innvandringsregulerende og barnefaglige hensyn i asylsaker er noe av det som har skapt mest debatt i Norge de siste årene. Et sentralt spørsmål er hvordan «barnets beste» blir forstått og vurdert og hvilken vekt dette skal tillegges i asylprosessen. Barnets beste er et grunnleggende hensyn som ikke bare gjelder utlendingsmyndighetenes behandling av den enkelte sak, det gjelder ved alle handlinger som berører barn.

Barn trenger forutsigbarhet og trygge rammer. Dette er behov det kan være vanskelige å ivareta både når det gjelder barn som kommer alene og barn som kommer sammen med sine foreldre eller andre familiemedlemmer. I rapporten Levekår for barn i asylsøkerfasen understreker vi behovet for å ta asylbarns levekår og omsorgssituasjon på alvor.

Først og fremst handler dette om å normalisere tilværelsen og skape trygge rammer. De minste må få tilbud om å gå i barnehage, skolebarn må få et opplæringstilbud som er tilpasset deres språklige, faglige og sosiale forutsetninger og ungdommer må gis rett til videregående opplæring - uavhengig av status i asylsaken. I en vanskelig livssituasjon, med mye stress og store belastninger, vil det være viktig at barna har aktiviteter som bidrar til mestring.

I tillegg må barns psykososiale situasjon tas på alvor. De må få hjelp til å takle traumatiske opplevelser og bistand til å håndtere usikkerhet og bekymringer. Det handler om å sikre stabile, trygge rammer og hjelpe barn og unge til å gjenskape kontinuiteten i livet. Forskning understreker at barn som blir boende lenge på asylmottak, er en spesielt utsatt gruppe. Kommunehelsetjenesteloven forplikter kommunen til å tilby nødvendige helsetjenester til alle som bor eller midlertidig oppholder seg der. Barn i asylmottak har dermed rett til primærhelse- og spesialisthelsetjenester. Spørsmålet er hvordan dette ansvaret blir ivaretatt, hvilke rutiner som finnes for å fange opp behov hos barn og unge i mottak, og hvordan samarbeidet mellom mottakene og de kommunale tjenestene fungerer.

Levekårene for barn i asylmottak påvirkes av en rekke ulike forhold i både fortid og nåtid. Barn reagerer forskjellig på ytre påkjenninger, men det er liten tvil om at flyktningtilværelsen påvirker helsen både psykisk og fysisk. Barn har behov for å føle tilhørighet, få omsorg og oppleve at de mestrer. Statlige og lokale myndigheter har ansvar for at asyltilværelsen skal bli så god som mulig, gjennom å legge til rette for gode boforhold, omsorg, aktivitetstilbud, sosiale nettverk og oppfølging fra et kompetent tjenesteapparat.

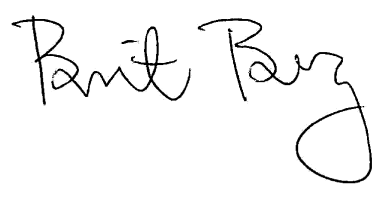

